GENDER AND CLASS FORMATION:

FEMALE CLERICAL WORKERS

\section{Heidi Gottfried}

$$
\text { and }
$$

David Fasenfest

Department of Sociology University of Michigan

November 1982
Copies available through: Center for Research on Social Organization University of Michigan 330 Packard Street Ann Arbor, Michigan 48109 
Gender and Class Formation:

Female Clerical Workers

Heidi Gottfried

and

David Fasenfest

Department of Sociology

University of Michigan

Ann Arbor, Michigan 


\section{Abstract}

Marxist categories, emphasizing class relations, essentially ignore the differential forms of women's struggles, and the ways in which gender relations shape class struggle and class formation. Accounts of class formation use indicators such as unionization and strike activity as a yardstick of class capacities, thus denying the particular conditions women workers face under a dual system of domination: capitalism and patriarchy. Within the workplace, theories of industrial conflict have underestimated the class capacities of women workers because of an apparent absence of unionization in sectors predominantly employing women. An examination of recent trends of female labor force participation, as well as of unionization among female workers overall and clerical workers in particular, reveals surprising results. Women are a significant percent of the total workforce, and an increasing percent of the total unionized workforce. Yet women work in occupations which have been regularly viewed as non-traditional arenas for unionization. Both the growth in female labor force participation and the rapid increase in the rate of female clerical unionization require that a better understanding of the factors which promote and retard unionization of female workers. We construct a model that explains class capacities of women workers using clericals as an example. This model differs from others in three major respects: a) it links macro- and microdimensions of the process of class formation; b) it broadens the focus from unionization, as the primary index of class formation, to other types of worker's organization as possible indicators of class formation; c) it examines the importance of gender to the capacity for class formation. 


\section{Introduction}

Marxist categories, emphasizing class relations, essentially ignore the differential forms of women's struggles, and the ways in which gender relations shape class struggle and class formation.l Accounts of class formation use indicators such as unionization and strike activity as a yardstick of class capacities, $\mathbf{2}$ thus denying the particular conditions women workers face under a dual system of domination: capitalism and patriarchy. 3 Within the workplace, theories of industrial conflict have downplayed, perhaps too hastily, the class capacities of women workers because of an apparent absence of unionization in sectors predominantly employing women. Consequently, researchers discount the potential for women workers' organization. Feminists, on the other hand, have unearthed organizations in the workplace which signal nascent class formation. They point to informal work groups and associations as important pre-union organization (Crompton, 1976; Bell, 1982; Barker and Downing, 1980), suggesting that non-union organization can constitute class formation in a less coherent form. Recent increases in the unionization of American women workers, furthermore, suggest that under some circumstances women can create durable organizations. The purposes of this paper are: a) to review evidence that challenges standard versions concerning class formation and b) to suggest an alternative theory for understanding the relationship between gender and class formation.

An examination of recent trends of female labor force participation, especially rates of unionization among female workers overall and clerical workers in particular, reveals surprising results. Many unions have begun to report their membership by occupation making it possible to identify significant increases in the 
number of clerical workers classified as union members. By examining changes between 1970 and 1978 for those unions which have made concerted efforts to unionize clericals, we find rapid growth of union membership. AFSCME, an important union for clerical organizing, increased its clerical membership from 71,140 to 183,600 ( $158 \%$ increase). Other notable increases for unions reporting data on clerical membership are the Office Employees Union (25\%), Retail Clerks (265\%) and the Teacher's Union (510\%). Overall, these unions saw an increase from 160,520 to 349,115 clerical members $(117 \%)$ over this time period (documentation was incomplete, in some cases the recording only started in 1978). The Postal Clerks reported 208,952 members of their union as clerical employees (figures for 1970 from BLS, 1971; figures for 1978 from BLS, 1979). These reported figures exclude data from the UAW, SEIU, and the Teamsters, all unions engaged in active organizing efforts among clerical workers over the past decade.

The increased rate of unionization among women workers, and especially female clerical workers, is most clearly seen through an examination of changes between 1977 and 1980 of workers both covered by and helonging to unions. While the total number of people represented by unions remained constant (or declined slightly) for this period, the opposite appears true for female clerical workers.

Table 1 about here

Increases in the total workforce -- male, female, and female clerical workers -- is shown in rable 1 for both workers represented by union contracts and actual members of unions. The total workforce has increased by $8 \%$ while total workers represented by contracts experienced only a $4 \%$ increased. Male union representation barely increased, in spite of an increase of male workers in excess of 


\begin{tabular}{lccc}
\hline Table 1 Changes in Employment and Unionization, 1977 & -1980 (thousands) \\
\hline & 1977 & $\underline{1980}$ & $\underline{\text { Percent Change }}$ \\
Total & 81264 & 87521 & $8 \%$ \\
Union Represented & 21535 & 22493 & $4 \%$ \\
Union Members & 19335 & 20095 & $4 \%$ \\
Male & 47316 & 49361 & $4 \%$ \\
Union Represented & 15236 & 15302 & $0 \%$ \\
Union Members & 14006 & 14039 & $12 \%$ \\
& & & $14 \%$ \\
Female & 34049 & 38048 & $14 \%$ \\
Union Represented & 6299 & 7191 & $15 \%$ \\
Union Members Only & 5329 & 6056 & $18 \%$ \\
Female Clericals & 12178 & 14047 & $19 \%$ \\
Union Represented & 1778 & 2093 & \\
Union Members Only & 1430 & 1707 & \\
& & & \\
\hline
\end{tabular}

Source: "Table 1. Employed Wage and Salary Workers Represented by Labor Organizations by Occupation, Sex and Race (BLS, 1978:6; BLS, 1981a:5)" and "Table 2. Employed Wage and Salary Workers In Labor Organizations by Occupation, Sex and Race (BLS, 1978:9; BLS, 1981a:8)"

(NB: totals may not add up due to rounding errors) 
$4 \%$ (reducing the percent of males covered by union contracts). In contrast, female employment increased at a rate $50 \%$ faster than total employment, female unionization increased at a rate $250 \%$ more than total unionization, and female clerical unionization was $30 \%$ higher than female unionization as a whole (or $3 \frac{1}{2}$ times the rate of increase in the total unionized workforce). These rates become even larger when only looking at actual union membership.

Clearly female workers are becoming unionized more rapidly than males, and female clerical workers are joining unions at an even greater pace. This trend appears to run counter to conventional wisdom concerning the willingness or capacity for unionization among secondary labor market employees. What factors account for this sudden increase in both the number and rate of clerical unionization? The task of this paper is to examine the factors which may explain this current phenomenon, recognizing the affects political and economic transformations have on the conditions of gender and class struggle.

Instead of focusing the inquiry on either the presence or absence of unionization as an index of class formation among women workers, a reconceptualization of class formation must investigate the ways patriarchy and capitalism, taken together, structure gender and class relations. We seek to construct a model that explains class capacities of women workers using clericals as an example. This model differs from others in three major respects: a) it links macro- and micro-dimensions of the process of class formation; b) it broadens the focus from unionization, as the primary index of class formation, to other types of worker's organization as possible indicators of class formation; c) it examines the importance of gender to the capacity for class formation.

Following a review of the literature, we present a general outline for the examination of class formation among female clerical workers. We then analyze 
various factors which we believe are central to any understanding of clerical organizational capacities, and which are summarized as:

1) factors which define the vulnerability and/or flexibility of employers (e.g., capital market structure);

2) factors which define the vulnerability of workers (e.g., labor market structure);

3) factors which define the class capacities of workers (e.g., labor process, pre-union organization);

4) factors which define the gender mechanism of labor control in the workplace (e.g., paternalism). 4

\section{Review of the Literature}

The model we develop in this paper draws heavily on marxist and socialistfeminist theory. 5 Although our model is situated in this discourse, it attempts to reconcile and clarify some theoretical issues; to elaborate our differences, we first review the literature on this question. Most scholarship which has a bearing on our question falls into one of three general theoretical schema: a) socialist-feminism developing a theory of gender mechanisms which hinder the development of working women's organization; b) labor market segmentation centering the discussion on the structure of capitalist production; c) marxist class analysis focusing on class relations and class capacities arising from the social relations of production.

Literature in the feminist tradition states that female unionization has been limited as a result of institutional arrangements and structural mechanisms; the lack of participation in unions on the part of women was not a voluntary process. Women, they state, are constrained by three main factors: a) union practices and hierarchical structures exclude women from the rank and file; b) job opportunities 
for women are systematically limited to a few job categories; and c) patriarchal relations in the family restrict the form of workforce participation. In the first instance, the internal leadership structure of unions staffed primarily by white males deterred women from joining the ranks of the "brotherhood". Secondly, unions excluded women from employment in the higher paid crafts. Many unions, particularly the AFL craft unions, didn't try to organize women workers; women, union leadership contended, were unorganizable (Blaxall and Reagan, 1976; Hartmann, 1979; Kessler-Harris, 1976).

The attitude manifest in the practice of unions, feminists argue, reflects the sexism embedded in the very structure of the union. Their research emphasizes the sex-gender system as one of male domination of women which is carried out at all levels and in all spheres of daily life (Kenneally, 1981; Milkman, 1981; Sokoloff, 1980; Women's Work Project, 1978; Union Wage, 1975; Zaretsky, 1973; Rubin, 1975). Women are denied access to unions and the benefits derived from unionization because of the control over these apparati by males desiring to ensure domination over women. "Men as a group share not only the material benefits from the exploitation and control of women's labor, but also a gender interest in maintaining their position of dominance (Sokoloff, 1980:154)."

Women's options in the labor market have been constrained by patriarchal and capitalist relations of domination. "The material base upon which patriarchy rests lies most fundamentally in men's control over women's labor power. Men maintain control by excluding women from access to some essential productive resources (...for example, jobs that pay a living wage) and by restricting women's sexuality (Hartmann, 1981:15)." As long as women maintain prime responsibility for household labor, they will be unable to participate in the labor market on an equal footing with men. In addition, job segregation by sex, Hartmann states, insures "that women 
have the lower paid jobs." Consequently, the gender division of labor "assures women's economic dependence on men and reinforces notions of appropriate spheres for women and men (Hartmann, 1981:22)." Men generally, albeit unequally, benefit from the unpaid domestic labor performed by women: as capitalists because they can both buy women's labor power at a low price, and can be assured of future generations of labor without direct payment; as husbands because they have more leisure time. Capitalists can, through the expropriation of women's labor by husbands or fathers at home, reduce the necessary wage which must be paid male workers to ensure a given standard for the family as a whole. In addition, when women enter the labor force, capitalists rationalize lower wages for female workers because a women's position in the household reduces her ability to demand higher wages. 6

Women's economic dependence on men, moreover, is legally reinforced by the state. Tax laws and social security policies, for example, assign men the role of the primary bread winner and distribute compensation accordingly. In addition, the family wage serves as a mechanism whereby men continue to control women's labor power at work and at home. The persistence of the family wage and relative lack of unions in the secondary labor market facilitate this utilization of women as a cheap source of labor (Hartmann, 1979).7

Generally, these socialist-feminist theories expect the organization of women to occur when organized labor or women's movement organizations target women for such efforts. Although they accurately describe the barriers to unionization encountered by women workers in the past, particularly in the late 19th and early 20 th centuries, these theories emphasize only one part of the story, to wit, the dual burden women experience in domestic work and wage labor. The theory tells us little about why women clericals are organizing, and in what parts of the economy 
this organization may be taking place.

We accept the basic argument made by the socialist-feminists that both patriarchy and capitalism structure the relations of domination and that each constitutes a separate but interconnecting system. However, we find the analysis incomplete. While the socialist-feminists have suggested new areas for research (e.g., an investigation of women's culture as a means of resistance), their theory still lacks an essential tool for determining the mechanism by which class formation of women workers occurs. A combination of socialist-feminist theory with recent marxist scholarship on dual labor markets and the proletarianization of work adds a dimension for a more general understanding of the role gender plays in class formation.

Theories grouped around the heading of labor market segmentation draw rough boundaries across the economy identifying characteristics of sectors effecting unionization. They suggest a correspondence between the structure of work and a given sector of the economy on one hand, and the propensity for unionization on the other. The economy is divided into primary and secondary sectors; primary sector firms tend to be larger (in the scale of production), more productive and more profitable while secondarv sector firms are smaller, tend to have lower capital/labor ratios (thereby being more labor intensive), are less profitable, and generally provide services rather than produce commodities.

Labor market segmentation theory focuses on the lack of unionization among women workers, locating women workers mainly within the secondary sector. Secondary labor markets are generally characterized by low wages, low skill requirements, limited career ladder opportunities, temporary or irregular work, and in general a set of features embodied in the organization of the work process which encourages a high attrition rate. It is these characteristics which create the 
circumstance unfavorable to unionization efforts (Edwards, Reich and Gordon, 1973; Doeringer and Piore, 1971). The theory provides a careful discussion of the conditions under which certain workers (primarily men) benefit from unionization. In addition, it outlines the underlying conditions whereby workers in the secondary labor market rarely unionize and consequently have generally lower wages. The theory fails, however, in explaining sex segregation within the labor market and how dual labor markets "came to be structured in the first place (Sokoloff, 1980:63)." Sokoloff states that the theory of segmented labor markets "simply assumes that (the structure) happens and describes the existing structure (1980:63)." In addition, she criticizes dual labor market theory for only focusing on those workers attached to the labor market and for not considering the totality of forces affecting a person's relations to markets, specifically refering to domestic work (c.f., Thomas, 1981; Conference of Socialist Economists, 1982). But more important for our analysis, the theory does not provide a basis for understanding why clericals have begun to unionize in the past decade. Using labor market segmentation theory, though, we may be able to draw some conclusions concerning deterrents to unionization after identifying the conditions favorable to clerical unionization.

Researchers approaching this problem from a Marxian class analysis generate two divergent views. The first, generally attributable to Poulantzas, would not expect clerical unionization because of clerical's class location in what he calls the new petite bourgeoisie. Marx's general classification that a worker is defined by his/her relations to the means of production is expanded to require that a worker must be engaged in productive labor (i.e. commodity production). Since clericals (in Poulantzas' scheme) are considered to live off the surplus produced by direct labor (they do not directly take part in the production of surplus value), they cannot be part of the working class. Rather, clericals are part of a nascent class formation 
(the new petite-bourgeoisie) resulting from the development of monopoly capitalism (Poulantzas, 1973, 1975; Wright, 1978). This sort of analysis, then, finds the absence of organized clericals not an aberration of but consistent with a class analysis of unionization. Given, however, that clericals are unionizing and that this model does not provide for an understanding of the conditions under which unionization can and does occur, an alternative view is necessary. Furthermore, Poulantzas' placement of clericals within this new class fails to capture the historical reality of their position within production. As elaborated below in the literature on proletarianization of labor, clericals constitute a growing portion of the working class, a position derived from relations of and in production. 8

The second approach within a Marxian class analysis framework focuses on forces and relations of production which create the possible conditions for workers' organizational capacities. The general model states that concentration of capital (i.e., monopoly capitalism) creates the internal requirement necessitating large clerical staffs for the coordination of the productive process (Braverman, 1974). As firm size expands, and the production process becomes more complex, firms hire an increasing number of clerical workers to work in a growing bureaucratic supervisory structure. At the same time, clerical workers (like production workers in general) find their jobs increasingly deskilled and degraded. This transformation cf clerical work, and the formation of "assemblyline" service production, it is argued, leads to a proletarianization of clerical labor.9 Clerical work, therefor, takes on more and more of the attributes of factory work (Braverman, 1974; Glen and Feldberg, 1979; Wright and Singleman, 1981). Proletarianization alone doesn't create the necessary conditions for workplace organizing. However, when this process is combined both with a consolidation of work whereby large numbers of workers are brought together under one roof, and with a coordinated labor process, then the potential for 
workplace organizing increases. The earlier isolation of clerical workers diminished their capacity to develop social networks necessary for organizing efforts (Glenn and Feldberg, 1979). While the proletarianization of the labor force under monoply capitalism also will form the basis of our analysis of clerical workers, the version presented here treats clerical work simply as an undifferentiated job classification -clericals include a wide varity of occupations and work processes. The proletarianization thesis underscores the general trend and not the specific conditions under which unionization of clerical workers might occur. Proletarianization of clerical work is not a necessary condition for unionization, but it may contribute to the recent unionization of these workers. Therefore, we must move beyond a theory of proletarianization of work to explain the rise in unionization among clerical workers.

\section{Theoretical Perspective}

Our model takes dual labor market theory as its starting point (as exemplified by Edwards, 1980), but departs from its mapping of the economy in basic ways.10 We attempt to transform its essentially descriptive categories into relational concepts. To perform this transformation, we: a) distinguish between capital markets (monopoly/competitve) and labor markets (primary/secondary);11 b) delineate a typology of labor process; and c) revise the formulation of the mechanism of control over workers to include hegemonic control based on gender (Burawoy, 1979).

The model we develop separates capital and labor markets -- labor markets define characteristics of the internal market structure and capital markets define characteristics of the external market (e.g., concentration of industry). Internal market structure defines the conditions confronting labor as a result of the labor process within a given proto-typic firm while external market structure defines the 
conditions resulting from the structure of that firm's industry. Following Edwards, we relate the structure of jobs with the labor market; primary labor markets offer more secure jobs, more extensive job ladders, employ more skilled labor within a more coordinated labor process utilizing higher degrees of capital to labor than do secondary labor markets. In contrast to Edwards' two-way categorization (linking monopoly capital markets with primary labor markets and competitive capital markets with secondary labor markets), we consider all four possible combinations of capital and labor markets. Table 2 samples various industries and identifies the dominant capital and labor characteristics found within them.

Table 2 about here

Therefore, for example, the telephone company exhibits monopoly characteristics in the capital market and yet can employ workers within both primary labor (installers) and secondary labor (operators and clericals) markets. Similarly mining, while basically competitive in its capital market structure, exhibits primary labor market characteristics. Capital markets should no longer be viewed as the sole determination of worker's organizational capacities. By separating capital and labor markets, we give the labor process a role as instrumental as the firm's location in either the monopoly or competitive capital market. In addition, this distinction recognizes that no fixed correspondence exists between capital and labor markets.

In addition to a capital and labor market distinction, a typology of labor processes (separating and ordering them in terms of their potential importance for determining variations in worker organizations) is necessary since the labor process both generates a range of opportunities for collective action and reflects different management stratagies of control over the workforce. In evaluating the importance 
Table 2 Capital and Labor Market Characteristics of Selected Industries

\begin{tabular}{lllccc} 
Industry & Capital & \multicolumn{4}{c}{ Labor Market } \\
& Markets & Skill & Tenure & C/L Ratio & Coord. \\
Auto & Monopoly & High & High & High & High \\
Steel & Monopoly & High & High & High & High \\
Mining & Competitive & High & High & Med & High \\
Construction & Competitve & High & Med & Med & High \\
Chemicals & Mixed & Med & Med & High & Med \\
Retail & Competitve & Low & Low & Low & Low. \\
Communications & Monopoly & Med & Med & High & Med \\
Banking & Competitive & Low & Low & Low & Low \\
Insurance & Competitive & Low & Low & Low & Low \\
Agricuture & Mixed & Low & Low & Med & High
\end{tabular}

(NB: All labor market characteristics refer only to workers, the ranks are relative to conditions generally faced by other workers, and within industries there exist variation. We try to indicate the dominant form for comparative purposes only.) 
of the labor process, we insert the worker into a pattern of social relations shaped by both the organization of production and the form of supervision. The components of the labor process are i) the organization 'of the work process ranging from atomized piece-rate work to team work, and ii) the ratio of capital to labor employed. If we dichotomize the first component into high and low coordination within the lahor process (COORD) and the second component into high and low capital/labor ratios $(\mathrm{C} / \mathrm{L})$, we can compare the propensity for unionization within any given capital market (SECTOR).

\section{Table 3 about here}

We argue, as rable 3 shows, that unionization occurs more often within a given capital market as capital/labor ratios increase and workers' tasks are more integrated and coordinated.

By combining capital markets (monopoly or competitive) consistent with the predictions in Table 3 above, we present a general model indicating propensities for labor organization across sectors.

Table 4 about here

Table 4 shows that while monopoly sector workers in general have a higher degree of unionization than competitive sector workers, we argue that certain aspects of the labor process can increase the potential for unionization in spite of the capital market sector of the firm.

Finally, the political dimension consists of the control strategies embodied in the organization of work (Edwards, 1980) and the type of political practice (i.e., despotic 
Table 3 The Propensity for Unionization Given the SEC TOR

$\begin{array}{ll}\text { LOW } & \text { C/L } \\ \text { MEDIUM-LOW } & \text { HIGH }\end{array}$

COORD
LOW
LOW
MEDIUM-HIGH

Table 4 The Propensity for Unionization by SECIOR, COORD and C/L

\section{SECTOR}

COMP

COORD

LOW $\quad \underline{\mathrm{HIGH}}$

$\underline{\mathrm{HIGH}}$

LOW3

MED2

$\dot{c} / L$

$$
\text { LOW }
$$$$
\text { LOW } 1
$$$$
\text { LOW }
$$

\section{MONOPOLY}

COORD

LOW $\quad$ HIGH

HIGHI

$\mathrm{HIGH} 2$

C/L: Capital Labor Ratio COORD: Degree of production coordination within the labor process SECTOR: Capital Market 
to hegemonic) within the workplace (Burawoy, 1980). The hegemonic system of control (this will be the system assumed in operation throughout this paper) depends on a rule by consent and must therefore present a system of social relations which reproduces class relations as a legitimate order. To develop an understanding of the specificity of gender relations in the workplace, we examine how patriarchy is incorporated within the capitalist system of production.

Class formation emerges from economic, political and ideological relations which determine the organizational capacities of the working class. These organizational capacities act to select and limit class formation. By organizational capacities we understand the means by which a class can promote its interests. Class capacities carry organizational capacities one step further, referring to the articulation of these objective class interests. By select we understand the process through which the range of possible outcomes are established via social mechanisms, and by limit we understand the process whereby only certain options within the range selected will actually be operational within this context (Wright, 1978). Our model of the development of class capacities is based on the material conditions of production (economic relations). Labor and capital market segmentation, in interaction with the labor process, directly selects and limits the organizational capacities and political activities of the working class. Even though economic relations are central in understanding the basis for organizational capacities, these relations are also affected by the same political activities of the working class which they were instrumental in forming -- both directly and through the political activities' effect on organizational capacity. Similarly, class capacities, embodying consciousness (ideology), selects and limits the forms of political activities available as ideology becomes itself transformed and reproduced by those same activities. Consciousness also both affects and is effected by the organizational capacities of the working 
class. Finally, it is these emerging organizational capacities which select and limit class formation.

This paper focuses on the potential forms of organizations of women working in the secondary labor market (specifically as clericals) either within the competitive or the monopoly capital sector. Worker organization takes on different forms: informal work groups, more formal associations of workers, and organized unions of clerical workers. These worker organizations correspond to increasing class capacities. Class and gender consciousness among clericals transforms organizational capacities, while organizational practice transforms the ideological content of clerical consciousness. However, consciousness cannot simply be reduced to a form of organization. Rather, the form of organization is structurally limited by labor markets, capital markets and the labor process.

\section{Women's Labor Force Participation}

By the end of World War II -- when Rosie the Rivetor supposedly turned in her overalls for an apron -- the number of working mothers increased tenfold over the level at the beginning of the war. More recently, women's labor force participation increased by 13 million compared to only 9 million more men. By 1981, 52.1\% of all women over 16 years old were in the labor force (BLS, 1981b:2) Contrary to the myth that women workers who marry permanently leave the workforce, 55\% of all mothers with children under the age of 18 years (16.6 million) worked full-time in 1979 and $45 \%$ of mothers with pre-school children performed a double shift of housework and wage labor (BLS, 1981b). According to Valerie Oppenheimer (1968), the majority of these women entered sex-typed jobs like clerical and other service work. Women cluster in the same 17 occupational categories available to them at the turn of the century (Blaxall and Reagan, 1976). 
Women have remained within the secondary labor market, mainly in the competitive sector of the economy, as a result of a process which cannot simply be explained by the logic of capitalist development. Early theories of class predicted the liberation of women under capitalism; relations between the sexes were to be transformed and replaced by class relations. As women were drawn into wage labor in the market, the hypothesis was that they would gain equal status with men as workers (Engels, 1968; Beneria, 1979). However, the historical reality proved theoretical expectations unfounded. Proletarianization of women, contrary to theory, lagged behind that of men due to the persistence of patriarchal relations. Without a theory of patriarchy and an understanding of the production and reproduction of gender relations, Engels subsumed gender under class conflict. To understand the development of the different levels of class formation among women and men, we must first investigate two related phenomena: a) the disparity between participation in the labor market by sex, and then consequently b) the variation hetween men and women workers' organizations once women gained entry into the labor market.

As we mentioned above, the socialist-feminists have developed a theory which accounts for the two phenomena. They argue that the solution lies in the relationship between capitalism and patriarchy (as intersecting systems). If we look into any household, we can discover the underlying reasons for gender inequality in the workplace. A woman, child in hand, dragging a vacuum across the livingroom rug while waiting for the buzzer on the new micro-wave oven to signal the completion of dinner, illustrates the way the domestic division of labor hampers her ability to participate fully in the workforce. Sokoloff (1980) appropriately refers to women's work experience as the dialectic of work in the home and the marketplace.

The remainder of the paper focuses 'on the workplace given the sexual division of labor in the family. We argue that the construction of gender relations is both a 
barrier and a basis for collective action.

\section{Vulnerability/Flexibility in Capital and Labor Markets}

Depending on their position in labor and capital markets (i.e., primary versus secondary and monopoly versus competitive respectively), both workers and employers will be more or less vulnerable and/or flexible in the scope of their actions. Labor intensive sectors of the economy, and for that matter divisions within a firm, must above all be concerned with wage levels if they are to keep production costs down. This is especially true in the secondary labor, competitive capital sector since low capital/labor ratios imply that labor costs comprise a major portion of the total costs of production. Control of these costs in part determines the potential profitability of the firm. If we assume unions mobilize to channel labor's dissatisfaction, especially over economic issues, then control over and manipulation of labor's potential to unionize must necessarily be an important objective of management. Monopoly sector firms (e.g., IBM and Bell Telephone) utilize a variety of programs and tactics to dissipate labor unrest and undermine workers' organizing efforts: office meetings and contests serve to diffuse moral problems at work; personal interest newsletters, periodic gifts and office parties create an atmosphere of collective interest and promote loyalty to the company; demerit systems to inforce work rules (and inhibit on-the-job organizing) and the firing of company defined trouble makers remove activists from the workplace. In addition, industries in the secondary labor and competitive capital sector will design their workplaces to discourage worker collaboration and association.

Firms relying on the secondary labor market in production have a particular interest in the maintenance of women as a reserve army of labor (Beechy,1977; Deckard and Sherman, 1974). Since labor constitutes the major portion of production 
costs, wages must be kept at a minimum (Edwards, Reich and Gordon, 1973; Cain, 1976). "Women in particular are a reserve army willing to work as part-time workers, to be used as needed. This practice of part-time work is handy, not only because it provides a labor supply, but also because it avoids the payment of fringe benefits (Deckard and Sherman, 1974: 481)." The lack of benefits and low wages promote high turnover 12 and undermine the formation of a continuous organizational core of employees. Women and minorities represent the majority of workers in secondary labor market jobs, and the appearance of women predominately in the secondary labor market cannot be considered random (Leacock, 1981).

Finally, O'Connor claims that unionization corresponds to monopoly sector production because monopoly sector firms, in general more profitable, desire labor peace to insure continuation of profitable production. Monopoly sector firms "buy" this peace, precisely because they can afford better contracts with unions or worker associations (O'Connor, 1973). We generally accept this thesis and include it in the model; clericals employed in monopoly sector firms are more apt to join unions and meet less resistance from employers than workers within the competitive sector.13 This willingness to accomodate labor in no way diminishes monopoly capital's desire to reduce wages where and whenever possible. However, greater vulnerability to labor unrest because of higher capital/labor ratios and greater profitability often translate into greater unionization and higher wages.

\section{Labor Process}

The rise of the organic composition of capital reflects an increase in both the scale of production and the concentration of capital. In the last decade, the organic composition of capital increased for firms in a secondary labor market once characterised by a high concentration of low-wage labor. To protect their capital 
investments, firms have restructured the work process. and developed an ensemble of political and ideological practices.

As firm size increases, and the production process becomes more complex, firms hire an increasing number of clerical workers (see page 9 above). Simultaneously, clerical workers (like production workers in general) find their jobs increasingly deskilled and degraded. This transformation of clerical work, and the formation of "assemblyline" production of services, leads to proletarianization of clerical labor (Braverman, 1974). The labor process itself is contradictory within capitalism. Gartman (1978) points out that Marx locates this contradiction as being between an increasingly socialized labor process and the private appropriation of the product of this labor. "The particular forces of production introduced by capital can only be really appropriated by a group of cooperative laborers (Marx, 1973)." Clerical work takes on more and more of the attributes of factory work, and it is this proletarianization which creates conditions under which women clerical workers potentially form organizations (Glen and Feldberg, 1979; Wright and Singleman, 1981).

In general, the socialization in the labor process of clericals leads to conditions favorable to union organization. The social relations within the production process is an important component in determining the likelihood of unionization. Clericals working in large clerical "factories", and who have little control over the pace of their work, are more apt to organized.14 Machine based work, e.g. visual display terminal (VDI) work, typing pools, and keypunching, exemplifies this tendency. The scale of production is as equally important as the pace of work. Clericals, concentrated in central areas and in large numbers, are more likely to develop the necessary solidarity for organizing than clericals employed by a single employer but scattered over a wide area in isolated offices.

Our discussion of the organization of work to this point has only mentioned the 
effects of the labor process on workers' organizational capacities. Ideological and political practices, which augment production, may also limit the possibilities for successful organizing efforts. Many offices have instituted various non-monetary incentive schemes, such as contests and a system similar to "making out" (Burawoy, 1979) for clerical workers. Usually some production quota, an office average to be met by all clericals, is set. Unlike the cooperative piece-rate system outlined by Burawoy, each player in this game does not depend on any other. The autonomous nature of work in clerical factories means that each player competes with her or himself to achieve the office average. Although all players have a common goal, they perform their tasks separately and independently; managers enforce the rules of the game. Because of the individuated nature of the work, disruptive actions by one person does not necessarily effect the work process for the rest. Therefore, if one person withdraws from production, that person may face dismissal. Such game playing inserts workers into the production process as individuals and not as collective actors; it enforces individualism and undermines collective action (Gottfried, 1982).

\section{Gender in Work}

So far in our discussion of class formation among clerical workers we have neglected the importance of gender formation. The employment of women primarily within the secondary labor market cannot simply be explained in terms of the logic of capitalism. In addition, women's position within the secondary labor market constrains, limits, and otherwise selects their organizational opportunies. Both of these aspects must be examined if the importance of gender is to be understood, since 
... it is the location in the job structure, not sex, that determines job commitment and other worker attitudes and behavior (Kanter, cited in Sokoloff, 1980:61)

As Kanter points out in the quote above, gender is produced and reproduced in the workplace. Our phrasing of the question concerning the role of gender in class formation, to this point, emphasized class. The question could be stated in reverse, i.e., what is the role of class in gender formation? The two are inexorably interconnected. The following specifically looks at the formation of gender subjectivity and gender relations within the workplace.

The construction of gender centers around sexuality and sexual relations. $A$ "feminine" sexual identity is usually enforced through office practices, most obviously in dress codes. Many so-called woman's jobs require as a condition of employment an appealing appearance. The job molds the female worker into a sex object -gender is recreated at work.15 Even women who don't come in contact with the "public" are encouraged to dress in a "feminine" manner (e.g., telephone operators and most clericals). Other gender specific attributes, such as courtesy, smiles and the like, often become incorporated into the performance of jobs held by women. As an example, telephone operators are rated according to "politeness" as well as technical ability to perform the necessary task (Gottfried, 1982).

Sexuality also enters into production politics as part of the institutional arrangements governing employee/employer relations. These power relations are usually expressed through paternalism.16 Paternalism embodies the structure of the labor market usually found in the secondary sector and involves informal political. practices. While male workers also face paternalism, it is not usually based on sexual practices (most notably workers of color are treated in this manner). Paternalism in the female job ghetto exhibits two forms: women tend to transfer their own aspirations onto their bosses and men commit acts of sexual harassment. 
These attitudes and behavior are built into the structure of the job.

The first form of paternalism stems from the structure of the labor market wherein women face dead end jobs and have little opportunity for mobility, consequently success is measured by the progress of their boss. Paternalism takes its toll in deterring organization by women. As an example, women clericals situated in high status offices less frequently join unions or other associations than their counterparts located at lower rungs of the job hierarchy.17 Although the clericals "at the top" may perform tasks identical to those sitting in typing pools, they respond differently in relation to disparate conditions on the job itself. For example, the personal secretary has more autonomy, less rigid work rules and paces her own work to some degree, while the secretary in a typing pool enjoys few of the above benefits.

The second gender manifestation based on sexuality within production is the sexual harassment of women workers. As stated above, forms of interpersonal relations are not merely the quirks of individuals but part of the structure of power relations in the office. Sexual harassment can serve two contradictory ends: a) as a method of social control; b) as a hindrance to efficient production. First sexual harassment, a form of conflict on an individual level, restricts solidarity in both a class and gender sense. Victims of sexual harassment are often held responsible by co-workers for precipitating the events, reinforcing divisions within the workplace. Second, since sexual harassment can disrupt production, rules are formulated to restrict its practice. Although these rules attempt to legislate the elimination of sexual harassment, they merely result in more subtle forms of harassment which are either allowed or ignored. Companies balance the cost of sexual harassment against its usefulness as a means of social control. Excessive sexual harassment, however, may create many negative consequences in production. Recently, as a result of 
women's groups' recognition and education of the prevalence of sexual harassment, women workers have begun to build more effective support networks. These support networks have, in many cases, heightened women's consciousness and, in so doing, increased their organizational capacities.

Finally, gender relations also come into play in the supervision of clerical workers. To promote the appearance of mobility, management often advances women from the ranks as supervisors. While advancement may provide models for female employees, it also divides female clerical workers from each other. Supervisors' sphere of control, and hence power, is severly constrained because little formal power is allocated to the position and because mid and top-level management -- overwhelmingly male -- dominate women supervisors on the shop floor. As a result, these women must rely as much on informal means of control over women under their jurisdiction as on formal command rules. Women supervisors often straddle a difficult position on the job' ladder. Neither squarely in management or labor, female supervisors act as management to workers and are treated as workers by management. In addition, traditional patriarchal relationships create a stronger acceptance of male authority than of female authority. As a consequence, female supervisors substitute harsh and aggressive behavior in carrying out their responsibilities to compensate for the inefficacy of their structural location. Correspondingly, women clericals react more strongly in opposition to their female supervisors. Female supervisors serve in the contradictory role of promoting the interests of capitalism as its managers while at the same time confronting and being subjected to the male domination inherent within capitalism in the form of male control over the means (and thereby the decisions) of production. The conflict between capital and labor is displaced onto the relationship between the worker and her immediate supervisor. 


\section{Informal Worker Organizations}

It is through an examination of the logic of capitalism and patriarchy that we gain an understanding of women's prospects for future organizing, and the reasons women take up the banner of unionization. Rosemary Crompton (1976) notes that marxists in general tend to overlook other, less traditional organizations of women at the workplace, (e.g. informal networks) because they do not constitute themselves into legal or other formal structures (like unions). She argues that measuring class formation by only using the presence of certified unions underestimates the importance of pre-union worker organizations in subsequent union campaigns. It is not uncommon to find clerical workers, and even white collar workers, forming associations at the workplace, especially in the context of larger offices. While informal organizations do not have the legal right nor the ability to force bargaining with the firm over economic and non-economic issues, they do indicate a level of worker collective consciousness. These bodies represent workers in their collective capacities and reflect workers' feelings that some type of organization is needed. We find Crompton's measurement of worker capacity according to pre-union organization an important contribution to understanding this growing trend.

Prior political participation and shared social interactions, Wagner (1979) suggests, support and anticipate workers' organization. In other words, organization was first defined by inclusion in the "brotherhood" or as professionals, and it was these pre-organizational forms which grew into the trade unions and the professional associations. In addition, he asserts clericals had no "positive history of group solidarity (Wagner, 1981)" prior to the formation of militant office worker organizations (inspired by the women's movement). Prior organizational history has been shown to be an important prerequisite to successful mobilization (Shorter and 
Tilly, 1974; Oberschall, 1973).

Industrial ethnologists examining industrial labor organizations link relations in the labor process with capacities to organize (Weir, 1973). The labor process can range from work teams to assemblyline production to individual input, representing a move from a coordinated to a fragmented organization of work. In many cases, informal work groups emerge which correspond to the structure of labor within the production process. In factories organized along the principle of work teams, workers are provided natural units through which to form these informal groups (Kornblum, 1974; Weir, 1973). Similarly, in clerical factories, new forms of informal worker associations may emerge. Therefore, we also must consider the possible variations within these networks to evaluate their impact on unionization efforts.

The transformation of informal worker organizations to a more class conscious form involves a complicated process. On the one hand, we don't expect an automatic transition from the lowest stage of organization to the most formal. Patterns of resistance within different work settings are uneven. On the other hand, there is evidence that unions appear more often in situations where prior worker organizations existed.18 Without better data we cannot pinpoint the exact process of transformation or the precise integration of the economic, political and ideological forces, yet we can suggest factors which might affect this process. As we have discussed above, changes in the economic conditions of women (e.g. the imperative to enter and remain in the workforce, and the rising importance of their incomes, especially for single parent households), changes in union practices (more unions are explicitly targeting women for organizing drives), and changes in the organization of production (especially as a result of new computer based technologies, cf. Gottfried, 1982) are factors which anticipate the transformation of informal work organizations to more formal structures. Recently, women workers' 
associations have adopted more traditional trade union tactics in dealing with management. Even nurses, who remain committed to the ideology of their "professionalism", have utilized the strike weapon in their pursuit of improved work conditions. In addition, management's failure to respond to grievances voiced by the workers has also politicized these associations. Finding the grievance procedures set up by management to be both ineffective and in the interest of management, workers may turn to unionization as a form of redress. In short, these associations provide the political experience for women workers necessary for unionization efforts, and the specific combination of economic, political and ideological factors present will determine the speed and likelihood of its occurrence.

\section{An Example: The Telephone Company}

The telephone company serves as a good illustration of the importance of both capital and labor markets in determining workers' organizational capacities. The most likely circumstance for clerical unionization occurs for highly coordinated labor in the monopoly sector under conditions of high capital/labor ratios. The financial structure of the telephone company places it within the monopoly capital sector. However, its labor market, characterized by a high capital/labor ratio and a low labor process coordination, locates it in the secondary labor market.

Telephone companies have had, with the help of government regulatory action, a virtual monopoly over the services it provides (Kolko, 1963; Danielson, 1939). Telephone rates are set to guarantee a "normal" rate of return on investments (e.g. a return equal to some market average for capital invested). Given predictable profitability and the ability to pass on increases in costs, we would expect (according to O'Connor's thesis) that the telephone company would concede better economic packages to strong unions. The case of the telephone company indeed 
seems to fit this pattern.

As a secondary labor market firm, the telephone company resembles that of other secondary sector firms, and not the large manufacturing firms commonly found in the monopoly capital markets. In contrast to industrial production where the assemblyline depends on an accumulation of work, telephone operators act independently of one another, with the actions of one operator having little bearing on work of another -- work stoppages initiated by a single worker would not interrupt the work flow. In addition, in order for an operator to halt incoming calls, a head-set must be unplugged which electronically alerts her superivsor. As a result of such monitoring, management can intervene rapidly, making collective action more difficult. Finally, the autonomous nature of the job is reinforced by the random scheduling of breaks and lunches by computers. These schedules are posted at the beginning of each workday, making advanced organizational planning during breaks difficult.

This individuation of work and the application of seemingly neutral technology exemplify the problems inherent in the workplace and which undermine workers' organizational capacities. Incorporation of rapidly changing technologies increasingly breaks-up the work process within telephone operating (Gottfried, 1982). The capital/labor ratio in telephone service is relatively high compared to most secondary labor market firms. However, even with the highly fragmented work process operators belong to a union--the Communication Workers of America. The monopoly status of the telephone company increases the propensity for union organization among operators, but the individuated labor process undermines the class capacities of the operators witnessed by relative labor peace in this work setting. 


\section{Considerations and Conclusions}

We argue that a model predicting clerical unionization must take into account three things: the structure of the capital and labor markets, the labor process and the organizational capacities of clerical workers (including the impact of patriarchal relations). Certain structural elements characteristic of firms located in the monopoly capital market must be present to provide a favorable climate for clerical unionization. As the above discussion about the telephone company pointed out, of equal importance to clerical unionization is the structure of the work process and the relations within the labor process. Workers need to be organized in work in ways which promote a certain degree of worker solidarity. The creation of clerical "factories", a by-product of proletarianization of clerical work, is but one example of this process. We feel that in spite of sectoral and structural factors, workers have to have an awareness of their organizational potential before effective clerical organizations will emerge.

The "ideal" conditions for unionization may be historically specific for various industries. In periods of economic expansion, for example, labor tends to be relatively scarce and employers may be willing to relax internal barriers to unionization for relative labor peace. In economic downturns, management may be more aggressive in their anti-union activities. It is especially true that during slack periods a growing number of laborers are unable to find jobs and join the reserve army of labor. These economic cycles can be either national or regional, in which case we may see patterns of one sort emerging in one region and different patterns emerging in another.

Veronica Beechy (1977), among others, suggest that a significant reserve army of labor will determine the relative success or failure of efforts by women employed in secondary labor market jobs to organize for better wages and working conditions. 
Women workers' capacity to organize is directly effected by the size of the surplus pool of labor. This is not unlike the limitations on blue collar workers' power to organize during periods of high unemployment. However, while the reserve army of labor makes its impact felt on the working class as a whole, women in particular suffer these consequences more acutely (Beechy, 1977; Anthias, 1980; Baran and Sweezy, 1966; Braverman, 1974). They, as a segment of the working class, tend to occupy the low skilled, low wage jobs and hence are more vulnerable to immediate replacement by this surplus labor in the event of labor unrest. The routinization and proletarianization of clerical work contributes directly to the degree of vulnerability of clerical workers' organizational capacities.

As Wagner (1979) correctly asserts, the women's movement and the resultant. "militant clerical worker groups" is a crucial variable in the determination of workers' capacities. Small informal "rap" groups, popularized by the women's movement, politicized women's informal groups in the workplace. In these rap groups, women together defined themselves and the direction for struggle. Although the banner of the women's movement primarily was carried and raised by middle class women, it did have pervasive and pervailing effects on gender relations overall. The women's movement inspired working class organizations such as the Coalition of Labor Union Women (CLUW), formed in 1975. In addition, many women active in the women's liberation movement took jobs as clericals and raised issues concerning power relations in the workplace. The same women began associations to support women workers. In the mid-70's, cities across the United States saw the rise of working women associations. These associations offered an organizational base for women; membership was drawn from many different workplace settings, especially among clericals (Dollars and Sense, 1975; Women's Work Project, 1978). In addition, these organizations assisted their members in the development of grievance 
procedures in still unorganized workplaces. Working Women, based in Cleveland, Women Employed in Chicago, Union Wage in San Francisco, and Nine to Five in Boston, increased women's bargaining power in the workplace. Out of Working Women and Nine to Five came the seeds of union organizing efforts, specifically that of local 925 of the Service Employees International Union (SEIU), which focuses on clerical worker organizing efforts.

Another factor contributing to the formation of workers' organizations is the changing demographics of the workforce; more women in clerical occupations remain in these careers, so that even an irregular pattern of employment (hopping from one clerical job to the next) commits them to the clerical workforce for longer periods than in previous decades. In addition, some worker groups have been fostered by the company (e.g., at IBM) as a direct response to the potential of workers' unionization. The case of the telephone company shows the unexpected consequences of forming company unions. The union established by $A \Gamma \& I$ served as the infrastructure for a national independent union and provided the organizational experience vital in the campaign to organize this ClO union in 1947 (Schacht, 1975).19

Any model explaining clerical unionization should take into account various determinations of class capacities, both sectoral and organizational. We can outline the necessary steps to test such a model in the following way. First, it is necessary to construct an index composed of measures of market share and the degree of capitalization to locate firms in either the primary or secondary sector of the economy. Next, changes in the relations in production should be recorded. These changes may result from any restructuring of the organization of work including changes in political practices (e.g. piece-rate system), technology, physical layout, etc (Burawoy, 1979). We would try to identify which factors contribute to 
the ability to unionize, and which may also develop countervailing tendencies mitigating against collective action under otherwise ideal conditions. Finally, the degree of pre-union activity can be measured by interviewing members of the union who were instrumental in the union's formation and by reviewing any historical documents in union files. This will provide some indication of the importance of prior organizational structures (both formal and informal) in the raising of collective consciousness as a precondition to unionization drives.

Finally, this analysis suggests a research agenda to test our hypothesis which could be undertaken in four parts. The first would be a disaggregation of unionization data for the purpose of identifying unionized clerical workers. This step is essential if we expect to uncover the reasons clerical workers, in spite of favorable conditions, fail in some cases to unionize. After having constructed a data base of unionized clericals, we would test our model to verify its predictability and reliability. The third step would be the generation of a list of potential workplaces which the model predicts should be unionized. Using this list, we can isolate workplaces with unorganized clericals and evaluate possible reasons for the absence of unionization. Lastly, we would try to outline the general conditions which impede clerical unionization given otherwise positive circumstances.

Women are a significant percent of the total workforce, and an increasing percent of the total unionized workforce. At the same time, we find that women work in occupations which have been regularly viewed as non-traditional arenas for unionization. Both the growth in female labor force participation and the rapid increase in the rate of female clerical unionization require that a better understanding of the factors which promote and retard unionization of female workers be forthcoming. It is our hope that this paper is a step in that direction. 


\section{Footnotes}

1. Much of the initial discussion about women's class position either accept the Marxian concept of class or propose a completely different logic to derive women's class position. Some socialist-feminists extended the meaning of productive labor to include the domestic labor of women. This domestic labor debate, as it came to be known, attempted to ascertain women's position viz-a-viz capital. Marxist-feminists focused on labor market participation. They linked the family to its function in the capital accumulation process. Capitalists utilized women as a reserve army of labor. Finally, radical feminists situated class relations within the sex gender system rather than the system of production. They defined class in gender terms; men generally exploited the labor of women and reproduced their dominance over women through a hierarchical social organization of production and reproduction. Constituting women as a class, as suggested by radical feminists, displaces the concept of class embodied in the relations of production. Our analysis is an attempt to understand class conflict and class formation within the context of the dynamic of change embodied in the conflict between women and men.

2. Implicit in our discussion of class formation is a definition of class formation as the outcome of production. Many recent neo-marxian theories, taking Gramsci as their starting point (cf., Green, 1982; Blee and Yago, 1982), stress the importance of cultural activities as constituting class relations; consequently these theories give equal weight to cultural phenomena and production. We believe dismantling the base/superstructure edifice muddles the analysis. These attempts fail

precisely because they do not anchor the daily life experiences of workers (as a class) to the relations in and of production. Although we recognize the possibility 
of class formation in other spheres besides the factory, we focus on this terrain because production facilitates class formation and because "even if production were neither the locus or focus of struggles, nevertheless it still determines where that locus and focus shall be (Burawoy, 1982:8-9)."

3. Patriarchy is defined as a "set of social relations between men which have a material base, and which . . establish or create interdependence and solidarity among men that enable them to dominate women (Hartmann, 1981:14)."

4. This typology was suggested by Erik Olin Wright in a review of an earlier draft.

5. There is an important theoretical (as well as political) distinction between marxist-feminism and socialist-feminism. The former accepts the basic class paradigm, subsuming gender conflict under class conflict while the latter adopts a dual systems approach. For socialist-feminists, patriarchy constitutes a system of social relations of domination. We will primarily use the socialist-feminist conceptualization throughout this paper.

6. The point is often raised that capitalists, following the logic of lower wages for female workers, can reduce their wage bill by merely substituting male workers with female workers. This line of reasoning fails to take into account two very important factors: a) white male workers have built organizations able to gain better wages and b) gender is an important means of control over workers. In the first instance, white male workers organize to directly demand increases in wages paid and to indirectly increase the standard of living which raises the "socially necessary" 
costs of reproducing their labor power. If male workers (whose wage reflects struggles over an increased share of the social surplus) were replaced by female workers (whose lower wage reflects historical impediments to their struggle for a larger share of the surplus), then one would expect conditions to emerge enabling women to unionize for increased wages. However, gender divisions serve in part to keep demands of male workers in line by maintaining a large core of underpaid or unemployed labor which could, as history has already proven, act as competently and productively as male workers in all facets of production. Assuming only capitalist logic of profit maximization leads one to expect increased feminization of production. Our analysis illuminates the mechanisms by which gender relations in production inhibit the class capacities of female workers, examiness the importance of patriarchal relationships for capitalism both in and out of work, and notes the changes in traditionally "female" work which has resulted in increased female (and especially clerical) organizing.

7. The Conference of Socialist Economist Collective on Class and Gender criticize Hartmann's theory of the family wage. They claim that while the family wage does exist, "it is more plausible, however, to recognize a family wage system was an interest of capital and, that the adoption of such an objective by the organized working class reflected their narrow vision of the struggle they were engaged in (CSE, 1982:88)."

8. Throughout this paper, we follow Burawoy (1979) and use relations of production to mean the modes by which surplus labor is extracted or expropriated from direct producers, relations in production to mean the relational aspect into which women and men enter as they confront nature in the transformation of raw 
materials into objects via the labor process and production politics to mean the set of mechanisms and political structures which guarantee the reproduction of the relations of production.

9. While we focus on the proletarianization of labor as an important criteria for understanding the formation of the working class, we do not deny the historical patterns of militant working class struggle led by skilled and artisanal labor. Our position here agrees with the view that artisanal workers formed organizations in response to their declining economic and political position brought about by the development of industrial capitalism. They struggled to prevent an erosion of their wages and income as production increasingly became fragmented. Proletarianization, we argue, results in a degree of homogenization of work in general, and thereby increases the potential for struggle in the workplace today.

10. We are indebted to Robert Thomas for his encouragement to pursue this line of thinking in his comments to an earlier draft.

11. While the role of the state remains a central question within a neo-Marxian debate on the state and capitalism, we feel that internal production politics in both the state and private sectors are similar for clerical workers and therefore we do not differentiate them in this paper.

12. Turnover has become institutionalized through the increased utilization of temporary workers. The literature, in particular the trade journal for office management, The Office, recognizes this trend; one article candidly anounced the use of temporary workers as a management tool (The Office, 1967-75; Gannon, 
1974). Throughout the seventies, those firms supplying temporary office workers have experienced a boom. Increasing employment of temporaries, along with high attrition rates, weakens clericals' ability to organize.

13. O'Connor's argument implies that unionization is most successful where it is most functional for capital. This functional argument ignores the importance of the working class' bitter struggle to form unions in the monopoly sector during the 1930's. Our model, similarly, could fall into the same trap if we don't acknowledge that capital's acceptance of unionization is only a by-product of hard won battles fought by workers. Recent attacts on labor, especially in the more unionized monopoly sector, has been manifest by the quality of work life programs and rising demands for concessions in mid-contract. The continued success of unions, even in the monopoly sector, requires an on-going struggle to safeguard gains won through struggle.

14. It is important to distinguish between total number of clericals employed in a given firm and the number employed in a coordinated process. Forty-five clericals working for a bank across fifteen branch offices, for example, unionize less frequently than twenty-five clericals working together in the central office of a corporation managing the operations of several factories. Wagner's (1976) assertion that larger units were less likely to unionize than small units is based, for the most part, on NLRB data defining bargaining units by the total number of employees in a firm. This form of aggregation fails to take into account the conditions under which clericals are employed.

15. Michael Burawoy pointed out to us that when males are employed in 
traditionally "female" jobs, they are also judged according to "feminine" characteristics like charm, poise, courtesy, personality and appropriate dress (e.g., airline stewards, bank tellers, sales personel). This further illustrates the degree to which gender is recreated by the job.

16. Here we use paternalism differently than does Burawoy (1982). He describes a political regime within which cultural patterns are constructed for workers and their families. Paternalism was possible as a political regime in a specific historical conjuncture; the tempering of the anarchic early capitalist market, resulting in a few firms possessing market power which could then be used to underwrite material concessions to workers. Consequently, social control became embedded in living arrangements, leisure activities and the like. Our use of paternalism, on the other hand, refers to the conflict between men and women based on sexual differences stemming from patriarchal relations.

17. According to Brendan Sexton, former Education Director of the United Automobile Workers (UAW), clericals found in university administration offices are less likely to join unions than their office pool counterparts. This became apparent during UAW organizing efforts in 1981 among clericals at Cornell University.

18. At a meeting on "Organizing Women Workers in the 1980's," Debbie Bell, economist for District 37 of AFSCME, made a guesstimate that there was a high correlation between unionization and prior worker's associations. Where associations are found, she stated, workers, and in particular women workers, will attempt to unionize more frequently, and with a higher success rate, than their counterparts in workplaces without prior worker organizations. 
19. Obviously, the formation of the Communication Workers of America (CWA) resulted from the general conditions in which monopoly sector workers in general mobilized during the 1930's. However, a quick scan of the successful unionization efforts among $\mathrm{ClO}$ unions reveals a pattern of development similar to that of the CWA. Many corporations, in response to the growing unionizing efforts of the 1910's and 1920's instituted company unions in an attempt to lull the worker's activities. In correspondence between the McCormick brothers of International Harvester, specific reference is made concerning the placement of a company union as a means to distract the workers from the ensuing union drive. These company unions, however, increased workers' organizational capacities to some extent. Instead of preventing independent unions, it allowed for worker contact with one another even though the issues discussed were defined by the company. Like the preorganizational associations of women workers, those male industrial workers who had belonged to prior organizations of workers, even company unions, had more organizational resources to apply to subsequent collective action and the formation of independent labor unions. 


\section{Bibliography}

Adderly, T. E.

1976 "Temporary Help as a Management Tool"

The Office, $84: 72$

Anthia, Floya

1980 "Women and the Reserve Army of Labour: A Critique

of Veronica Beechy",

Capital and Class, (Spring)

Baran, Paul and Paul Sweezy

1966 Monopoly Capital

New York, Monthly Review Press

Barker, Jane and Hazel Downing

1980 "Word Processing and the Iransformation of the Patriarchal

Relations of Control in the Office"

Capital and Class, (Spring)

Beechy, Veronica

1977 Some Notes on Female Wage Labour"

Capital and Class, (Winter)

Bell, Debbie

1982 "Organizing Women Workers in the 1980's"

Panel discussion at the Marxist School, New York City, June 10

Benaria, Lourdes

1979 "Reproduction, Production and the Sexual Division of Labor"

Cambridge Journal of Economics, 3:203-225

Blaxall, Martha and Barbara Reagan (eds.)

1976 Women and the Workplace: Implications of Occupational Segregation

Chicago, University of Chicago Press

Blee, Kathy and Glenn Yago

1982 "The Political Economy of Exploitation: A Revision"

Insurgent Sociologist 11 (Spring): 63-72

Braverman, Harry

1974 Labor and Monopoly Capital

New York, Monthly Review Books

Burawoy, Michael

1982 "Karl Marx and the Satanic Mills"

Unpublished Manuscript, University of Wisconsin

1979 Manufacturing Consent

Chicago, University of Chicago Press 
Bureau of Labor Statistics

1981a Earnings and Other Characteristics of Organized Workers Department of Labor, Bulletin 2105

$1981 \mathrm{~b}$ Employment in Perspective: Working Women Department of Labor, Report 663

1979 Directory of National Unions and Employee Associations Department of Labor, Bulletin 2079

1978 Earnings and Other Characteristics of Organized Worker Department of Labor, Report 556

1971 Directory of National Unions and Employee Associations Department of Labor, Bulletin 1750

Cain, Glen

1976 "The Challenge of Segmented Labor Market Theories to Orthodox Theory: A Survey"

Journal of Economic Literature, 14:4

Conference of Socialist Economists

1982 "Sex and Class Collective Report"

Capital and Class, (Spring)

Crompton, Rosemary

1976 "Approaches to the Study of White Collar Unionism" The Journal of the British Sociological Association, 10:3

Danielian, N. R.

1939 A. T. T.: The Story of Industrial Conquest New York, Vanguard Press

Deckard, Barbara and Howard Sherman

1974 "Monopoly Power and Sex Discrimination" Politics and Society, 4:475-482

Doeringer, Peter and Michael Piore

1971 International Labor Markets and Manpower Analysis Lexington, D. C. Heath

Dollars and Sense

1975 "Clerical Workers Organize,"

Dollars and Sense, 6(April):4-5

Edwards, Richard

1980 Contested Terrain New York, Basic Books

Edwards, Richard, Michael Reich and David Gordon

1973 Labor Market Segmentation Toronto, D. C. Heath \& Co. 
Eisenstein, Zillah (ed)

1979 Capitalist Patriarchy and the Case for Socialist Feminism New York, Monthly Review Press

Friedman, Andrew

1977 Industry and Labour: Class Struggle at Work

Under Monopoly Capitalism

London, MacMillan Co.

Gannon, Martin J.

1974 "A Profile of Temporary Help Industry and Its Workers" Monthly Labor Review, 95:44-49

Gartman, David

1978 "Marx and the Labor Process: An Interpretation"

The Insurgent Sociologist, VIII: II \& III

Ginzberg, Eli

1971 "Introduction"

in Robert Smuts, Women and Work in America

New York, Schoken Books

Glen, Evelyn Nako and Roslyn L. Feldberg

1979 "Proletarianization of Clerical Work: Technology and Organizational Control in the Office", in Andrew Zimbalist (ed.), Case Studies in the Labor Process New York, Monthly Review Press

Gottfried, Heidi

1982 "Keeping the Workers in Line: Pink Collar Automation" Science for the People, (June)

Green, Jim

1981 "Culture, Politics, and Workers' Response to Industrialization in the U.S."

Radical America, 16 (Jan-Apr):101-130

Hartmann, Heidi

1981 "The Unhappy Marriage of Marxism and Feminism: Toward a More Progressive Union", in Lydia Sargent (ed.)

Women and Revolution

Boston, South End Press

1979 "Capitalism, Patriarchy and Job Segregation by Sex", in Zillah Eisenstein (ed.), Capitalist Patriarchy and The Case for Socialist Feminism

New York, Monthly Review Press

"How Business is Using Temporary Help"

1970 The Office, 73:87-89 
Kaplan, Temma

1979 "Female Consciousness and Collective Action: The Case of

$1 \quad$ Barcelona, 1910-1918"

Signs 7 (Spring):545-566

Kessler-Harris, Alice

1976 "Women, Work and the Social Order"

in Berenice P. Carroll, Liberating Women's History

Chicago, University of Illinois Press

Kolko, Gabriel

1963 Triumph of Conservatism: A Reinterpretation of

American History, 1900-1916

London, Free Press

Kornblum, William

1974 Blue Collar Community

Chicago, University of Chicago Press

Leacock, Eleanor

1981 "Introduction"

in Helen Safiotti, Women in Class Society

New York, Monthly Review Press

Mark, Karl

1973 Grundrisse

New York, Vintage

1967 Capital

New York, International Publishers

McDonough, Roisin and Rachel Harrison

1978 "Patriarchy and Relations of Production" in Kuhn and Wolpe (eds.)

Feminism and Materialism

London, Rutledge and Kegan Paul

Milkman, Ruth

1980 "Organizing the Sexual Division of Labor: Historical Perspectives

on Women's Work and the American Labor Movement"

Socialist Review, 10 (Jan-Feb):95-150

Oberschall, Anthony

1973 Social Conflict and Social Movements

Englewood Cliffs, N.J., Prentice-Hall

O'Connor, James

1973 Fiscal Crisis and the State

New York, St. Martins Press

"Office Workers are Efficient Temporaries"

1970 The Office, 72:40-42 
Oppenheimer, Valerie

1968 "Sex-Labeling of Jobs"

Industrial Relations 非 (May)

Rubin, Gayle

1975 "The Traffic in Women" in Rayna Reiter (ed.),

Toward an Anthropology of Women

New York, Monthly Review Press

Schacht, John

1975 "Toward Industrial Unionism: Bell Telephone Workers and Company Unions, 1911-1937"

Labor History (Winter)

Shorter, Edward and Charles Tilly

1974 Strikes in France, 1830 to 1968

London, Cambridge University Press

Sokoloff, Natalie

1980 Between Money and Love: The Dialectics of

Women's Home and Market Work

New York, Praeger Press

"Temporary Help in Business Today"

1975 The Office, 82:18-20

"Temporary Help Services Save Employer's Money"

1973 The Office, 79:67

Therborn, Goran

1980 Ideology of Power and Power of Ideology

London, New Left Books

Thomas, Robert

1981 "Citizenship, Gender and Work Organization: Considerations

for Labor Process Theories"

Center for Research on Social Organization

Working Paper 非231 (March)

University of Michigan, Ann Arbor

Tilly, Charles

1978 From Mobilization to Revolution

Reading, Mass., Addison-Wesley

Union Wage

1975 Organize

Berkley, Union Wage 
Clerical Unionization, page 43

Vogel, Alfred

1971 "Your Clerical Workers Are Ripe For Unionism"

Harvard Business Review, (March-April)

Wagner, David

1979 "Clerical Workers: How 'Unorganizable' Are They?"

Labor Center Review, 2:1

Weir, Stan

1973 "The Informal Work Group"

in Synd, Alice and Staughton (eds.)

Rank and File

New Jersey, Princeton University Press

"What Business Thinks About Temporary Help"

1975 - The Office, 79:14-15

Wright, Erik Olin

1978 Class, Crisis, and the State

London, New Left Books

Wright, Erik Olin and Joachin Singleman

1981 "The Proletarianization of Work in American Capitalism"

Institute for Research on Poverty

Discussion Paper 非47-81 (March)

University of Wisconsin, Madison

Women Work Project

1978 Women Organizing the Office

New York, Union for Radical Political Economy

Zaretsky, Eli

1973 "Capitalism, the Family, and Personal Life"

Socialist Revolution, (January-April) 